\title{
Pengembangan Instrumentasi dan Analisis Sinyal EMG pada Otot Leher
}

\author{
Nabilah Ashriyah, Tri Arief Sardjono, dan Mohammad Nuh \\ Departemen Teknik Biomedik, Institut Teknologi Sepuluh Nopember (ITS) \\ e-mail: sardjono@bme.its.ac.id
}

\begin{abstract}
Abstrak-Orang yang telah kehilangan laring (laryngectomee) atau mengalami kerusakan laring akan kehilangan fungsi bicara dan menyebabkan sulitnya berkomunikasi. Electrolarynx (EL) adalah perangkat genggam berdayakan baterai yang merupakan salah satu alternatif untuk membangkitkan suara dengan memberi getaran pada otot leher. EL adalah alternatif yang mudah digunakan dan sederhana, akan tetapi suara yang dihasilkan EL tidak natural (seperti robot), monoton, dan memiliki kualitas yang rendah sehingga dibutuhkan pengembangan lanjut untuk meningkatkan kualitas suara dan kenyamanan penggunaan. Penelitian sebelumnya telah menunjukkan adanya hubungan antara aktivitas otot leher dengan pembentukan suara. Oleh karenanya, sinyal elektromiografi (EMG) pada otot leher dianalisis terhadap intensinya untuk memulai/berhenti bicara dan hubungannya dengan nada suara yang dihasilkan. Pada penelitian ini, instrumentasi EMG minimum dirancang untuk memperoleh sinyal EMG pada otot leher. Instrumentasi EMG terdiri dari penguat instrumentasi, rangkaian filter, dan rangkaian adder. Sinyal EMG kemudian direkam dan dilakukan proses filtering, rectification, dan kalkulasi envelope sinyal sederhana dengan low pass filter Pole-Zero. Korelasi amplitudo envelope EMG dengan sinyal suara ketika berbicara dianalisis. Thresholding sinyal EMG dengan batas ambang ganda (onset/offset) diusulkan dalam mendeteksi sinyal wicara. Hasil penelitian ini menunjukkan bahwa perekaman sinyal EMG pada otot leher membutuhkan instrumentasi dengan penguatan yang jauh lebih besar. Nilai threshold untuk onset mampu mendeteksi sinyal wicara sebelum wicara terjadi dengan selang waktu sekitar 0.2 ms. Akan tetapi, offset threshold tidak mampu memberikan waktu akhir dari sinyal wicara dengan tepat, di mana deteksi wicara diakhir lebih cepat sekitar 0.12 ms dari seharusnya.
\end{abstract}

Kata Kunci-Deteksi Suara, Elektromiografi Otot Leher, Korelasi.

\section{PENDAHULUAN}

$\mathrm{L}$ ARYNGECTOMEE adalah orang yang mengalami pengangkatan laring (laringektomi) atau kerusakan laring, baik karena kanker laring maupun penyakit laring lainnya. Kebanyakan laryngectomee adalah orang tua di atas usia 50 tahun dan disebabkan oleh rokok dan alkohol [1]. Pasien laringektomi ini akan kehilangan fungsi bicara dan menyebabkan sulitnnya berkomunikasi sehingga membutuhkan suara pengganti, seperti esophageal speech (ES), tracheoesophageal (TE) speech, dan electrolarynx (EL) speech [1]. ES dan TE merupakan alternatif yang menghasilkan suara lebih alami dan paling umum digunakan di Indonesia, hanya saja proses rehabilitasi ini cenderung lama hingga pasien benarbenar terlatih dan dapat berbicara kembali dengan baik. Selain sulit, sering kali suara yang diucapkan kurang jelas untuk dimengerti oleh lawan bicara [2]. Sedangkan EL adalah perangkat genggam berdaya baterai untuk membangkitkan suara dengan memberi getaran pada otot leher yang kemudian menggetarkan sistem vokal. EL dianggap alternatif yang paling sederhana, mudah digunakan, dan efektif dibandingkan dengan dua alternatif sebelumnya. Penggunaan EL juga dirasa aman dan tidak memerlukan perawatan khusus. Akan tetapi, EL masih memiliki kelemahan pada suaranya yang tidak natural, monoton, dan memiliki kualitas yang masih rendah.

Wicara EL yang monoton dan tidak natural seperti robot membuat pasien sulit berekspresi. Oleh karena itu, diperlukan pengembangan sistem EL yang dapat mengubah frekuensi getar transduser secara adaptif untuk memberikan intonasi suara. Selain peningkatan kualitas wicara EL, EL juga dapat dikembangkan dari segi kenyamanan dan efisiensinya. Electrolarynx yang bebas genggam (hands-free) dengan kontrol on/off otomatis menjadikan EL lebih praktis dan akan membuat pasien lebih fleksibel.

Beberapa penelitian telah menunjukkan adanya hubungan antara aktivitas otot leher dengan pembentukan suara. Beberapa penelitian untuk mengembangkan kontrol EL dengan memanfaatkan sinyal EMG, khususnya pada otot leher, telah dilakukan. Penelitian tersebut termasuk untuk kontrol on/off yang mengatur daya transduser EL [3][4][5], kontrol nada suara EL dengan mengestimasi frekuensi getar transduser [6][7][8], dan analisis untuk kontrol volume EL [9].

Sinyal EMG pada otot leher yang berhubungan dengan pembentukan suara bernilai sangat kecil, sekitar puluhan microvolt [3]. Oleh karena itu, pada penelitian ini dilakukan pengembangan instrumentasi EMG untuk otot leher yang dapat merekam sinyal EMG otot leher dengan baik. Selain itu, analisis sinyal EMG juga dilakukan terhadap intensinya untuk memulai/berhenti bicara dan korelasinya terhadap frekuensi fundamental dari sinyal suara yang dihasilkan.

\section{TINJAUAN PUSTAKA}

\section{A. Sistem Suara pada Manusia}

\section{1) Gambaran Umum dan Prinsip Kerja}

Suara dihasilkan ketika suatu objek (sumber) bergetar dan menyebabkan udara di sekitarnya bergerak. Produksi suara manusia pada sistem suara (vocal tract) pada dasarnya dimulai dari perintah sistem saraf dalam kontrol otot dan manipulasi rangkaian organ penghasil suara [10]. Produksi suara berawal dari aliran udara di sistem suara yang bersumber dari aktivitas respirasi. Pengeluaran udara inspirasi dari paru-paru keluar melalui trakea dan laring akan memberi gaya tekanan yang menggetarkan pita suara di dalam laring. Getaran pita suara 


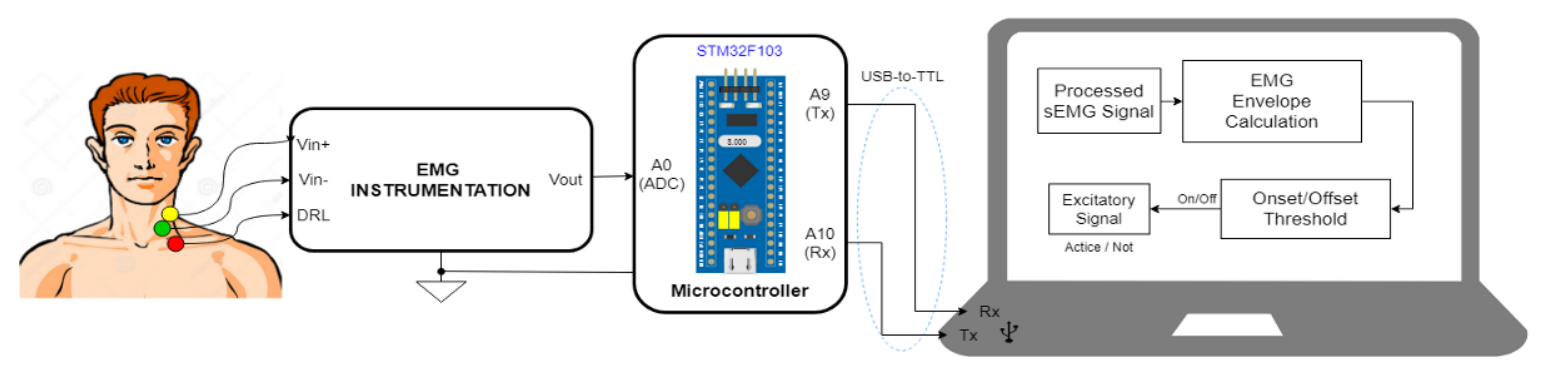

Gambar 1. Diagram blok rancangan sistem instrumentasi EMG untuk mendeteksi suara.

kemudian beresonansi dan suara yang dihasilkan akan diartikulasikan oleh komponen artikulator, seperti lidah, gigi, dan bibir.

2) Peran Laring dalam Produksi Suara

Laring terdiri dari empat kartilago utama, yaitu: tiroid, krikoid, dan dua aritenoid [11]. Kartilago-kartilago ini membentuk struktur yang mendukung dan menaungi pita suara. Ketika dikontraksi secara diferensial, otot-otot laring intrinsik dapat menggerakkan kartilago yang saling bergantung satu sama lain untuk membuka dan menutup glotis melalui manuver abductory dan adductory, serta untuk memodifikasi panjang dan sifat mekanik dari jaringan pita suara. Gerakan ini dieksekusi pada skala waktu yang sama dengan artikulator lainnya seperti lidah, bibir, rahang, dan velum. Getaran, yang menyebabkan permukaan pita suara bergerak maju mundur ratusan kali per detik dan menghasilkan bunyi, terjadi ketika konfigurasi permukaan medial pita suara, sifat mekanisnya, dan kondisi aerodinamis di sekitarnya cukup memadai untuk memulai dan mempertahankan osilasi diri.

\section{B. Elektromiografi}

Elektromiografi (EMG) adalah disiplin yang berhubungan dengan deteksi, analisis, dan pemanfaatan sinyal listrik yang berasal dari kontraksi otot [12]. Akuisisi data sinyal listrik tersebut dilakukan menggunakan instrumen elektromiograf, dan hasil rekamnya disebut elektromiogram.

Karakteristik sinyal EMG adalah sinyal acak atau stokastik yang amplitudonya berkisar dari 0 sampai $1,5 \mathrm{mV}$ (root mean square) atau 0 sampai $10 \mathrm{mV}$ (peak-to-peak) dengan rentang frekuensi antara $0-500 \mathrm{~Hz}$, dengan energi dominan pada rentang $50-150 \mathrm{~Hz}$ [13].

Untuk merekam sinyal EMG, ada dua jenis sensor yang dapat digunakan, yaitu elektroda jarum dan elektroda permukaan (kulit). Umumnya elektroda jarum digunakan untuk mengukur aktivitas unit motoris tunggal dan elektroda permukaan untuk mengukur mengukur unit-unit motoris.

\section{Hubungan antara Sinyal Elektromiogram dengan Pembentukan Suara}

Proses pembentukan suara manusia membutuhkan kontraksi otot-otot komponen pembentuk sistem vokal, termasuk kontraksi otot-otot laring intrinsik pada saat fonasi. Kontraksi otot pada pita suara dan getaran yang terbentuk menunjukkan adanya keterkaitan antara aktivitas otot dan nilai spektrum suara yang dihasilkan.

Otot cricothyroid dan strap merupakan otot utama pada leher yang terlibat dalam menurunkan nada (pitch lowering) pada kontrol laring. Otot cricothyroid menunjukkan adanya penurunan aktivitas selama penurunan nada, sebaliknya pada otot strap terjadi peningkatan aktivitas otot selama penurunan nada [14].

Selain otot yang telah disebutkan sebelumnya, aktivitas otot sternocleidomastoid juga telah diteliti keterkaitannya dengan proses pembentukan suara. $\mathrm{Yu}$ et al. dalam studinya menganalisis otot sternocleidomastoid untuk sEMG based Electrolaynx [15]. Studi tersebut menunjukkan bahwa semakin tinggi nada suara, amplitudo sinyal otot sternocleidomastoid akan menurun.

\section{Instrumentasi EMG}

Instrumen EMG adalah alat pengukur sinyal bioelektrik untuk mengetahui sinyal yang disebabkan oleh aktivitas otot. Instrumentasi EMG ini terdiri dari beberapa bagian yang disusun secara cascade, yakni: penguat instrumentasi, rangkaian common-mode rejection, rangkaian filter analog, dan adder.

\section{1) Penguat Instrumentasi}

Tegangan yang dihasilkan oleh kontraksi otot sangat kecil (microvolts) dan pengukuran tersebut berisiko kehilangan integritasnya karena adanya derau dari gerakan kabel atau interferensi elektromagnetik. Untuk mencegah degradasi sinyal, voltase sinyal dikuatkan secara diferensial oleh preamplifier. Penguat instrumentasi (instrumentation amplifier) merupakan suatu penguat differensial yang memiliki impedansi masukan yang tinggi dan arus bias masukan yang rendah dan memiliki output tunggal dengan impedansi yang rendah. Rangkaian penguat instrumentasi yang baik harus mampu memberikan common-mode rejection ratio (CMRR) yang tinggi, rendah derau, tegangan offset yang rendah, nonlinearitas yang rendah, anti-interferensi yang tinggi dan bandwidth yang memadai [16].

\section{2) Rangkaian Common-Mode Rejection}

Penguat instrumentasi adalah rangkaian yang menguatkan perbedaan tegangan antara dua sinyal masukan sembari meniadakan sinyal yang sama-sama muncul (common) di kedua masukan, dinamakan common-mode rejection $(\mathrm{CMR}) . V_{\mathrm{CM}}$, tegangan common, dapat disebabkan oleh beberapa ketidaksamaan, seperti perbedaan impedansi elektroda, impedansi kabel, maupun rangkaian pelindung rangkaian (umumnya resistor, kapasitor, dan dioda) pada input penguat instrumentasi. Salah satu cara untuk mengurangi tegangan common pada output adalah dengan menggerakkannya kembali ke tubuh pasien dengan rangkaian yang disebut sebagai 


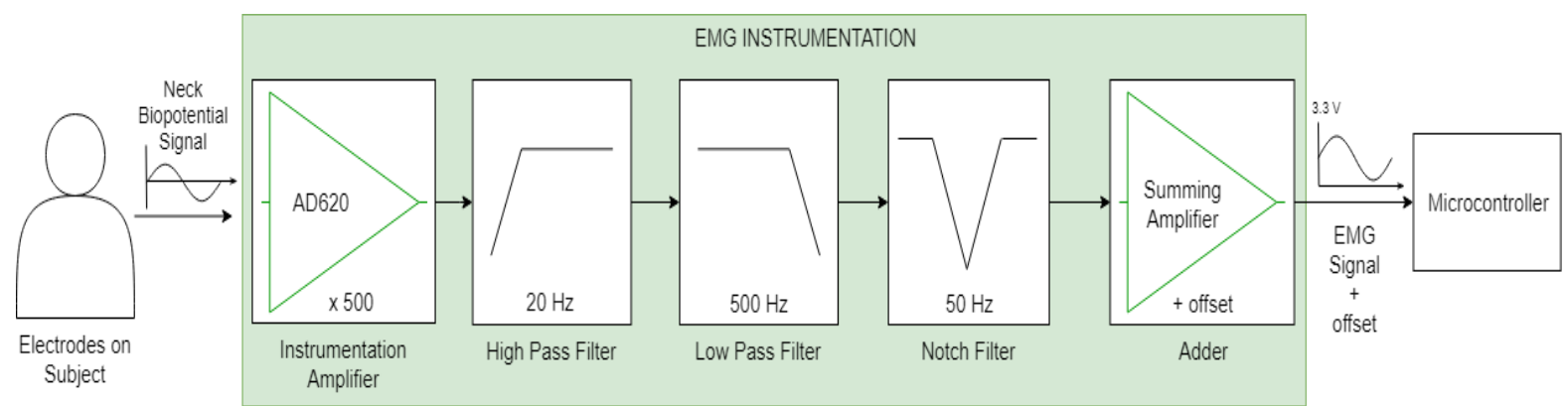

(a)

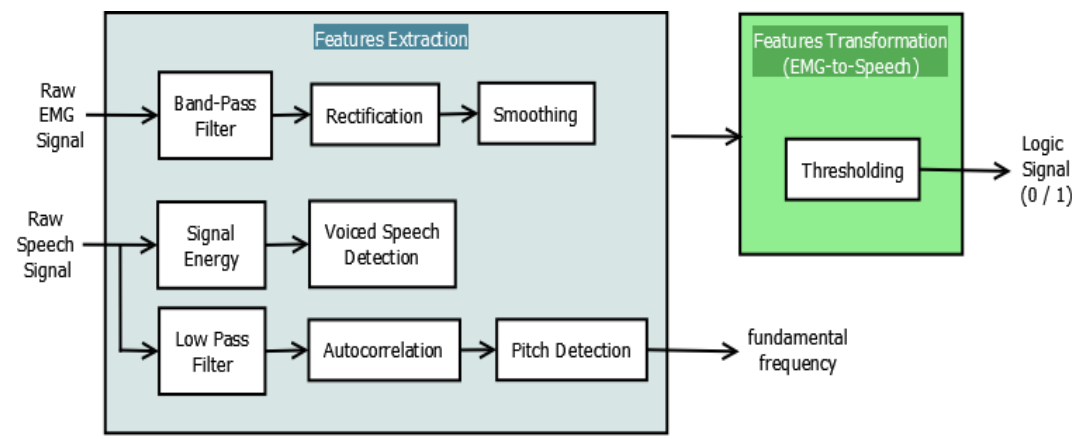

(b)

Gambar 2. Diagram blok rancangan perangkat keras (a) dan perangkat lunak (b) pada sistem.

rangkaian right leg drive (RLD). Pada RLD, sinyal common mode dibalik dan diredam agar bisa mendekati nilai nol.

\section{3) Rangkaian Filter}

Filter adalah rangkaian yang didesain to meloloskan suatu pita frekuensi tertentu sembari meredam semua sinyal di luar pita. Rangkaian filter dapat berupa aktif ataupun pasif. Filter pasif hanya terdiri dari resistor (R), induktor (I), dan kapasitor (C). Filter aktif adalah rangkaian elemen RC pasif, dan satu atau lebih elemen aktif [17]. Elemen aktif (op-amp) ini berfungsi sebagai sumber tegangan yang men-drive output dari filter pasif. Ini memungkinkan filter aktif untuk men-drive impedansi beban atau tahap lain dalam kaskade filter multistage tanpa mengubah karakteristik filter yang mungkin terjadi dalam filter pasif dengan impedansi tinggi yang menyebabkan tegangan dan respons frekuensi output dapat terpengaruh [18]. Pada penelitian ini, rangkaian filter RC digunakan dengan rumusan penentuan frekuensi sudut sebagai berikut:

\section{4) Rangkaian Adder}

$$
f_{c}=\frac{1}{2 \pi R C}
$$

Rangkaian adder adalah rangkaian yang berfungsi sebagai penambah level tinggi tegangan suatu sinyal. Rangkaian ini merupakan summing amplifier, yaitu operational amplifier yang digunakan untuk mengkombinasikan antara dua atau lebih sinyal.

\section{PERANCANGAN SISTEM}

\section{A. Sistem Keseluruhan}

Secara keseluruhan, sistem ini terdiri dari instrumentasi EMG, dan mikrokontroler beserta dua pemrosesan sinyal untuk sinyal EMG dan sinyal suara yang dilakukan di personal computer (PC). Alur kerja sistem instrumentasi EMG untuk merekam sinyal EMG otot leher dirancang seperti pada Gambar 1. Pertama, instrumen EMG akan mengambil data berupa sinyal listrik dari aktivitas otot leher yang memiliki korelasi dengan pembentukan suara. Kemudian, sinyal dikirimkan ke mikrokontroler (ADC) untuk mencacah sinyal analog menjadi sinyal digital. Mikrokontroler selanjutnya mengirimkan sinyal digital EMG ke PC. Pada PC, dilakukan pemrosesan sinyal EMG dan komputasi untuk mendeteksi sinyal suara. Jika hasil thresholding sinyal EMG adalah "on”, maka sinyal suara terdeteksi dan berakhir jika sinyal "off".

Sistem ini dapat dibagi menjadi dua bagian: perangkat keras dan perangkat lunak. Perangkat keras di sini merupakan instrumentasi EMG yang dirancang untuk dapat memperoleh data sinyal EMG yang bernilai kecil (milliVolts) agar dapat terbaca oleh mikrokontroler dan diolah secara digital. Perancangan perangkat keras dapat dilihat pada Gambar 2.

Sementara itu, perangkat lunak merupakan serangkaian proses untuk dapat memperoleh informasi sinyal suara dan sinyal EMG yang diperlukan, serta mengubahnya menjadi informasi lain yang dianalisis untuk mendapat nilai korelasi antara keduanya.

\section{B. Rangkaian Penguat Instrumentasi}

Penguatan sinyal EMG awal pada instrumentasi EMG ini menggunakan penguat instrumentasi terintegrasi AD620. Pada penelitian ini, resistor penguatan $R_{G}$ yang digunakan adalah resistor variabel $100 \Omega$ yang diparalel dengan dua resistor ratarata $24 \mathrm{k} \Omega$ sehingga diperoleh nilai penguatan minimumnya sesuai dengan formula dari datasheet sebagai berikut.

$$
G=\frac{49.4 k \Omega}{R_{G}}+1=\frac{49.4 k \Omega}{100 \Omega \|(24 k \Omega+24 k \Omega)}+1 \cong 495
$$




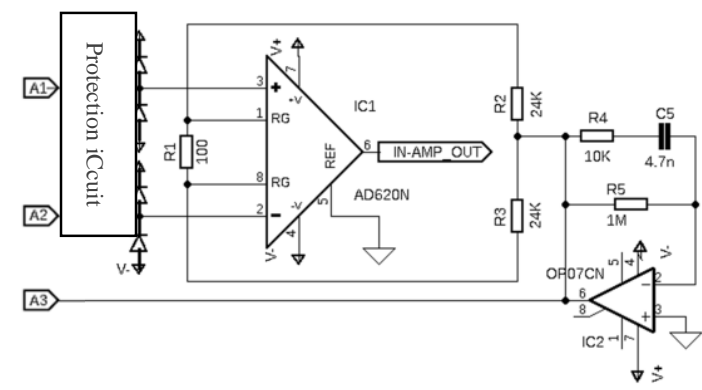

Gambar 3. Desain rangkaian penguat instrumentasi dengan common-mode rejection.

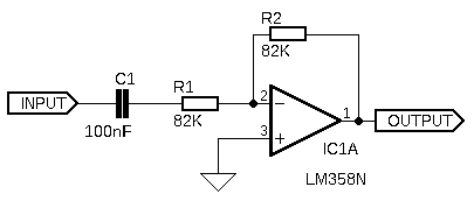

Gambar 4. Desain rangkaian high-pass filter $+20 \mathrm{~dB} / \mathrm{dec} 20 \mathrm{~Hz}$.

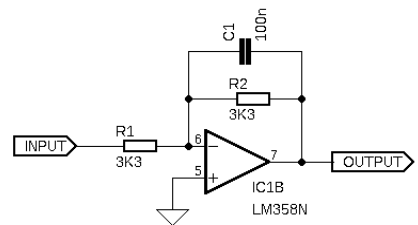

Gambar 5. Desain rangkaian low-pass filter-20 dB/dec $500 \mathrm{~Hz}$.

\section{Rangkaian High-Pass Filter}

Rangkaian high-pass filter orde 1 dirancang menggunakan filter aktif dengan frekuensi cut-off $20 \mathrm{~Hz}$ dan penguatan 1 (unity gain) seperti pada Gambar 4. Perancangan rangkaian filter dengan frekuensi cut-off tersebut dilakukan untuk menghilangkan sinyal $D C$ drift yang berada pada frekuensi rendah.

\section{Rangkaian Low-Pass Filter}

Rangkaian low-pass filter orde 1 dirancang menggunakan filter aktif dengan frekuensi cut-off $500 \mathrm{~Hz}$ dan unity gain seperti pada Gambar 5. Perancangan rangkaian filter dengan frekuensi cut-off tersebut dilakukan untuk mengambil sinyal EMG yang bandwidth-nya mencapai $500 \mathrm{~Hz}$ dan menghilangkan sinyal lainnya yang berada di atas $500 \mathrm{~Hz}$.

\section{E. Rangkaian Notch Filter}

Rangkaian notch filter orde 1 dirancang menggunakan filter Twin-T dua op-amp dengan frekuensi cut-off $50 \mathrm{~Hz}$ dengan nilai kedalaman faktor $Q$ sebesar 2.5 seperti pada Gambar 6 . Perancangan rangkaian filter dengan frekuensi cut-off tersebut dilakukan untuk menghilangkan sinyal jala-jala listrik oleh sumber listrik PLN yang tidak bisa dihindari.

\section{F. Rangkaian Adder}

Rangkaian adder berfungsi sebagai rangkaian pengatur baseline offset agar sinyal EMG dapat terbaca dengan baik oleh ADC mikrokontrol yang tidak bisa membaca nilai negatif. Rangkaian dirancang dengan nilai tegangan offset maksimum adalah 3.3 V. Desain rangkaian adder dapat dilihat pada Gambar 7.

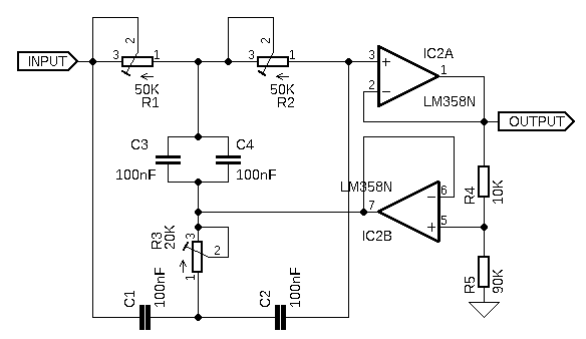

Gambar 6. Desain rangkaian notch filter $50 \mathrm{~Hz}$.

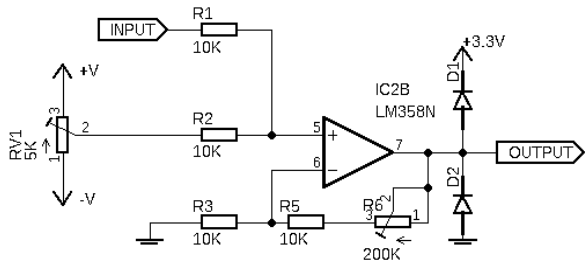

Gambar 7. Desain rangkaian adder.

\section{G. Akuisisi Data}

Pada penelitian ini, mikrokontroler STM32F103C8 compact board, 'Blue Pill' digunakan untuk mengakuisisi data sinyal EMG pada ADC channel 12-bit. Mikrokontroler di sini berfungsi mencacah sinyal analog EMG menjadi sinyal digital dengan sampling rate tertentu. Sampling rate ditentukan 1000 Hz. Setiap sampel data yang diterima ADC (per $1 \mathrm{~ms}$ ) kemudian dikirimkan ke PC melalui komunikasi serial (USART).

Data sinyal EMG dan sinyal suara diakuisisi (dan disimpan) secara bersamaan dengan sampling rate sinyal suara ditentukan 11,025 Hz. Kedua data sinyal diakuisisi dan diolah menggunakan program IDE object-oriented Pascal.

\section{H. Kalkulasi Envelope Sinyal EMG}

Kalkulasi envelope EMG merupakan bagian dari proses ekstraksi fitur sinyal EMG. Tahap ini termasuk didalamnya proses filtering dan rectification secara digital [19]. Filtering dilakukan untuk mengembalikan baseline sinyal EMG menjadi nol dengan high pass filter dan menghilangkan gangguan jalajala listrik di $50 \mathrm{~Hz}$ dan harmoniknya di $150 \mathrm{~Hz}, 250 \mathrm{~Hz}, 350$ $\mathrm{Hz}$, dan $450 \mathrm{~Hz}$, serta Low Frequency Noise di $100 \mathrm{~Hz}$ dengan notch filter.

HPF: $y(n)=K[x(n)-x(n-1)]+a y(n-1)$

di mana $K=\frac{1+a}{2}$ dan ditentukan $a=0.98$

Notch: $y(n)=K[x(n)-2 \cos (\theta) x(n-1)+x(n-2)]+$

$$
2 r \cos (\theta) y(n-1)-r^{2} y(n-2)
$$

di mana $K=\frac{1-2 r \cos (\theta)-r^{2}}{2-2 \cos (\theta)}, \theta=2 \pi f_{c}$, dan ditentukan $f_{c}=50 \mathrm{~Hz}, 100 \mathrm{~Hz}, 150 \mathrm{~Hz}, 250 \mathrm{~Hz}, 350 \mathrm{~Hz}, 450 \mathrm{~Hz}$.

Rectification adalah proses integrasi sinyal EMG agar hanya sinyal bernilai positif saja yang diambil. Pada penelitian ini dilakukan full-wave rectification, yakni seluruh sinyal EMG diabsolutkan sehingga sinyal yang bernilai negatif menjadi positif. 


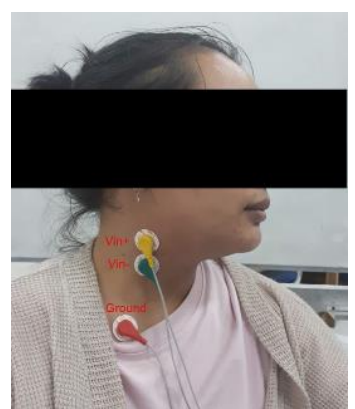

Gambar 8. Posisi peletakan elektroda pada otot sternocleidomastoid.

$$
y(n)=|x(n)|
$$

Kemudian, envelope sinyal EMG diperoleh dengan melewatkan sinyal hasil rectification ke low pass filter. Pada tahap ini, sinyal difilter dengan frekuensi potong $5 \mathrm{~Hz}$ [20].

$$
\begin{aligned}
& y(n)=K[x(n)-2 x(n-1)+x(n-2)]+ \\
& 2 r \cos (\theta) y(n-1)-r^{2} y(n-2)
\end{aligned}
$$

di mana $K=\frac{1-2 r \cos (\theta)-r^{2}}{4}, \theta=2 \pi f_{c}$, dan ditentukan $f_{c}=5 \mathrm{~Hz}$.

\section{Ekstraksi Fitur Sinyal Suara}

Pemrosesan sinyal suara dibagi menjadi dua alur, yakni kalkulasi energi jangka pendek dan autocorelation. Kalkulasi energi jangka pendek merupakan bagian ekstraksi fitur sinyal suara untuk deteksi (waktu) wicara, sedangkan autocorrelation merupakan metode untuk deteksi frekuensi fundamental dari sinyal suara. Keduanya proses dilakukan setiap segmen sinyal suara di mana panjang segmen ditentukan 27 milidetik.

\section{J. Energi Jangka Pendek}

Energi jangka pendek adalah penghitungan energi dari sinyal suara yang dilakukan secara tersegmentasi. Energi jangka pendek akan memberikan informasi variasi nilai amplitudo per segmen yang dapat menunjukkan apakah sinyal suara mengandung voiced speech (sedang berbicara) atau unvoiced speech (sedang diam). Voiced speech secara umum memiliki amplitudo yang lebih besar daripada unvoiced speech. Energi dihitung pada domain waktu dengan moving average filter:

$$
y(n)=\sum_{i=0}^{M-1} x(n-i) \cdot w(i)
$$

di mana $y$ adalah keluaran filter, $x$ adalah sinyal suara masukan, $M$ adalah lebar window atau segmen untuk perhitungan energi jangka pendek, dan $w$ adalah fungsi window yang digunakan. Fungsi wondow yang digunakan untuk ekstraksi fitur sinyal suara di sini adalah Hamming:

$$
w(n)=0.54-0.46 \cos \left(\frac{2 \pi n}{M-1}\right)
$$

\section{K. Deteksi Frekuensi Fundamental}

Sebelum dilakukan deteksi frekuensi fundamental suara, sinyal melalui tahapan pre-processing terlebih dahulu, yaitu filtering. Filtering dilakukan menggunakan low pass filter sebelum menghitung frekuensi fundamental setiap segmen sinyal suara guna menghilangkan sinyal harmonik yang terkandung dalam sinyal suara untuk menghindari kesalahan deteksi frekuensi fundamental suara. Frekuensi fundamental suara manusia umumnya berada di bandwidth $60 \mathrm{~Hz}$ hingga 300 Hz. Oleh karenanya, sinyal suara difilter dengan low pass filter menggunakan (4) dengan frekuensi potong $f_{c}$ adalah $300 \mathrm{~Hz}$.

Setelahnya, dilakukan autocorrelation untuk mendeteksi frekuensi fundamental per segmen suara. Korelasi antara dua sinyal dilakukan untuk mengukur kemiripan keduanya yang hasilnya ditunjukkan sebagai fungsi time lag di antara mulainya dua sinyal. Autocorrelation merupakan korelasi suatu sinyal dengan dirinya sendiri pada interval waktu yang berbeda. Fungsi diskrit autocorrelation tersegmentasi (finite) dapat didefinisikan sebagai:

$$
R_{x x^{(k)}}=\sum_{i=0}^{M-1} x(n-j) \cdot x(n-j+k)
$$

Autocorrelation dapat digunakan untuk mendeteksi frekuensi fundamental suara dengan mencari nilai maksimum $R x x$ yang diperoleh. Nilai (index) lag yang terdeteksi adalah besar frekuensi fundamental terukur dengan rumusan:

$$
f_{0}=\frac{f_{s}}{l a g} \mathrm{~Hz}
$$

\section{Thresholding}

Thresholding adalah prosedur untuk mendeteksi adanya sinyal wicara berdasarkan amplitudo EMG yang dihasilkan otot leher. Tahap ini merupakan proses penyamaan waktu sinyal suara dan sinyal EMG terekam untuk menentukan amplitudo envelope sinyal EMG minimum ketika voiced speech terdekteksi dan ketika beralih menjadi unvoiced speech (akan berhenti berbicara). Ketika amplitudo envelope sinyal EMG melebihi onset threshold, maka sinyal logika 1 dihasilkan (aktuator aktif). Sebaliknya, jika amplitudo envelope sinyal EMG kurang dari offset threshold, maka sinyal logika 0 dihasilkan (aktuator tidak aktif).

Penentuan amplitudo envelope sinyal EMG minimum sebagai threshold, baik onset maupun offset, dilakukan secara manual dengan merata-ratakan nilai yang didapat pada semua subjek dan menurunkannya 10\% dengan maksud untuk menghindari delay (transduser mulai bergetar lebih lambat dari waktu onset sebernarnya atau berhenti lebih cepat dari waktu offset sebernarnya). Pada penentuan threshold, perlu dipastikan bahwa threshold untuk offset harus lebih rendah dari onset untuk menghindari kesalahan deteksi [1].

\section{Peletakan Elektroda}

Peletakan elektroda yang tepat merupakan hal yang penting dalam menganalisis sinyal listrik aktivitas otot yang memiliki keterkaitan dengan pembentukan suara. Neck strap muscle menjadi bagian otot yang umum dipelajari dalam penelitian EMG-EL sebelumnya, khususnya bagian sternohyoid muscle [3], [4], [7], [8], [20]. Akan tetapi, bagian neck strap muscle beresiko tinggi mengalami dampak dari prosedur operasi pengangkatan laring sehingga sulit atau bahkan tidak bisa digunakan untuk fungsi kontrol EMG-EL. [15] dalam penelitiannya mempelajari aktivitas nonlaryngeal muscle, sternocleidomastoid dan inferior belly of omohyoid, yang dikatakan memiliki keterkaitan dengan nada suara. Dalam studinya, penulis membandingkan kedua otot dalam mendefinisikan nada suara yang dihasilkan dalam pengucapan 
Tabel 1.

Nilai envelope maksimum EMG yang diperoleh ketika mulai dan akan berhenti berbicara.

\begin{tabular}{ccc}
\hline \multirow{2}{*}{ Data } & \multicolumn{2}{c}{ Nerhenti berbicara. } \\
\cline { 2 - 3 } & Mulai & Berhenti \\
\hline Sampel 1 & $1.38682285341039 \times 10^{-2}$ & $7.00274980551793 \times 10^{-3}$ \\
Sampel 2 & $4.58813985231996 \times 10^{-2}$ & $4.97125279239748 \times 10^{-2}$ \\
Sampel 3 & $5.11197050980926 \times 10^{-2}$ & $1.09078754908183 \times 10^{-1}$ \\
Sampel 4 & $1.26806897863844 \times 10^{-2}$ & $9.41343396783817 \times 10^{-3}$ \\
Sampel 5 & $1.51825007718730 \times 10^{-1}$ & $9.19470249970504 \times 10^{-2}$ \\
Sampel 6 & $4.65246258214402 \times 10^{-2}$ & $5.31676434183100 \times 10^{-2}$ \\
Rata-rata & $5.36499425803251 \times 10^{-2}$ & $45760305002982 \times 10^{-2}$ \\
\hline \hline
\end{tabular}

Tabel 2.

Perbandingan nilai amplitudo maksimum envelope sinyal EMG dan pitch yang terdeteksi.

\begin{tabular}{cc}
\hline \hline Amplitudo Envelope Sinyal EMG & Pitch Terdeteksi \\
\hline $1.79 \mathrm{E}-01$ & 167 \\
$7.50 \mathrm{E}-02$ & 175 \\
$1.47 \mathrm{E}-01$ & 181 \\
$1.16 \mathrm{E}-01$ & 184 \\
$6.03 \mathrm{E}-02$ & 193 \\
$6.17 \mathrm{E}-02$ & 197 \\
$2.70 \mathrm{E}-01$ & 200 \\
$8.37 \mathrm{E}-02$ & 204 \\
\hline \hline
\end{tabular}

kata-kata dalam bahasa Kanton. Penulis menyimpulkan otot sternocleidomastoid merupakan otot nonlaryngeal yang mungkin bisa diandalkan untuk memprediksi frekuensi fundamental suara sebagai $s E M G$-based pitch control karena amplitudonya yang lebih besar dikarenakan otot ini terletak langsung di bawah kulit (tidak terhalang otot lain).

\section{PENGUJIAN DAN ANALISIS SISTEM}

\section{A. Pengujian Instrumentasi EMG}

Pada pengujian instrumentasi EMG keseluruhan, dilakukan perekaman sinyal EMG pada otot sternocleidomastoid ketika mengucapkan kata "A". Gambar 9a menunjukkan sinyal EMG yang terekam.

\section{B. Pengujian dan Analisis Algoritma Kalkulasi Envelope $E M G$}

Pengujian algoritma kalkulasi envelope EMG pada setiap prosesnya ditunjukkan pada Gambar 9 yang sinyal masukannya merupakan sinyal EMG ketika mengucapkan kata 'A'. Berdasarkan selubung sinyal EMG, dapat dilihat bahwa ketika aktivitas listrik pada otot terdeteksi, maka amplitudo selubung sinyal EMG akan meningkat. Besar amplitudo selubung sebanding dengan absolut tegangan sinyal EMG yang terekam.

Hasil tersebut digunakan untuk menganalisis adanya aktivitas listrik pada otot terkait ketika berbicara. Mengamati grafik sinyal EMG tersebut dapat terlihat bahwa ada perubahan sinyal EMG ketika mulai berbicara dan akan berhenti berbicara. Artinya sinyal EMG pada otot leher dapat diukur saat suara diproduksi. Akan tetapi, sinyal yang dihasilkan sangat kecil sehingga perlu nilai penguatan yang besar dan sinyal ini rentan akan noise. Salah satu noise yang dapat menutup sinyal EMG (a)
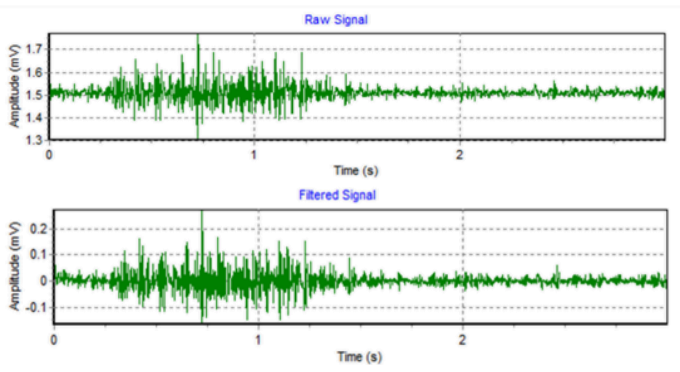

Rectifed Signal

(C)

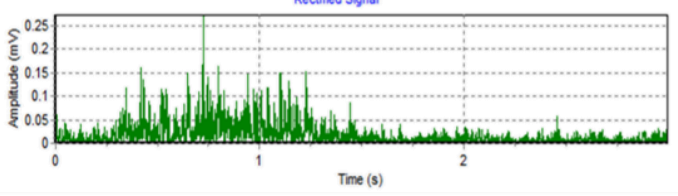

Signal Envelope

(d)

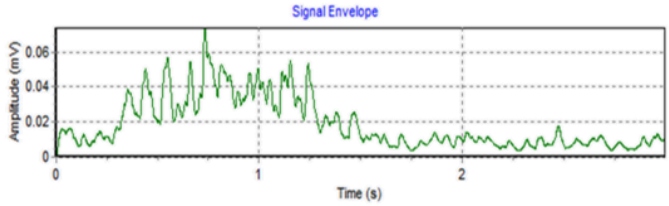

Gambar 9. Grafik untuk setiap proses algoritma kalkulasi selubung sinyal EMG secara berurut. Grafik menunjukkan sinyal EMG mentah yang diterima PC (a), hasil HPF dan notch filter (b), rectification (c), dan LPF (d) sebagai hasil akhir, yaitu envelope EMG.

(a)

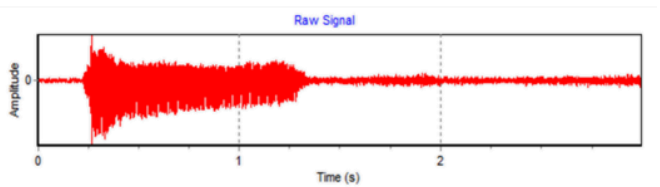

(b)

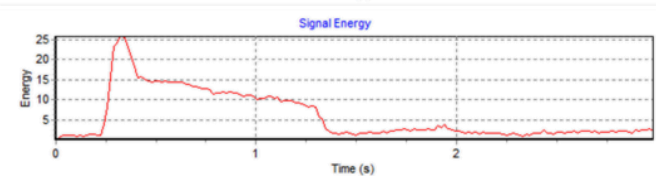

Gambar 10. Sinyal suara terekam dan energi yang dihasilkan. (a) menunjukkan sinyal suara mentah yang diterima oleh PC dan sinyal masukan algoritma energi jangka pendek. (b) menunjukkan hasil algoritma energi jangka pendek dari sinyal suara masukan

leher adalah sinyal pada frekuensi rendah yang amplitudonya bisa lebih besar dari sinyal EMG leher itu sendiri.

\section{Pengujian dan Analisis Algoritma Energi Jangka Pendek Sinyal Suara}

Pengujian algoritma energi jangka pendek sinyal suara dilakukan menggunakan sinyal suara yang mengucapkan kata "A" ditunjukkan pada Gambar 10a. Sinyal suara tersebut diambil bersamaan dengan data EMG pada Gambar 9a. Hasil pengujian algoritma ditunjukkan pada Gambar 10b. Dapat dilihat, ketika subjek memulai mengeluarkan suara maka energinya meningkat, dan menurun ketika akan berhenti / diam.

\section{Pengujian dan Analisis Algoritma Deteksi Frekuensi Fundamental Sinyal Suara}

Pengujian algoritma deteksi frekuensi fundamental sinyal suara dilakukan menggunakan sinyal masukan yang sama dengan pengujian algoritma energi jangka pendek sinyal suara (Gambar 10a). Grafik pada Gambar 11a menunjukkan hasil sinyal terfilter. Kemudian dihitung autocorrelation sinyal 
(a)

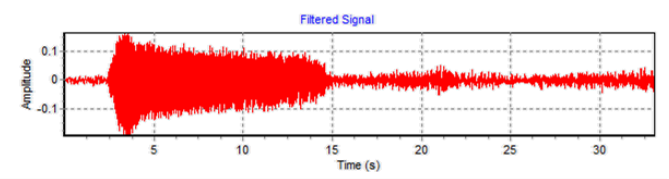

(b)

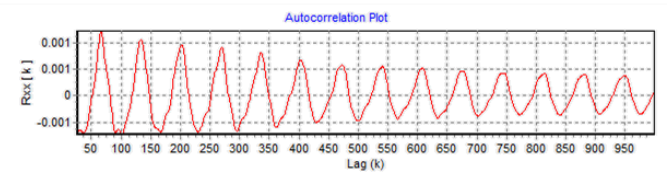

(c)

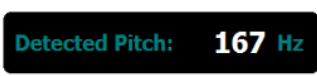

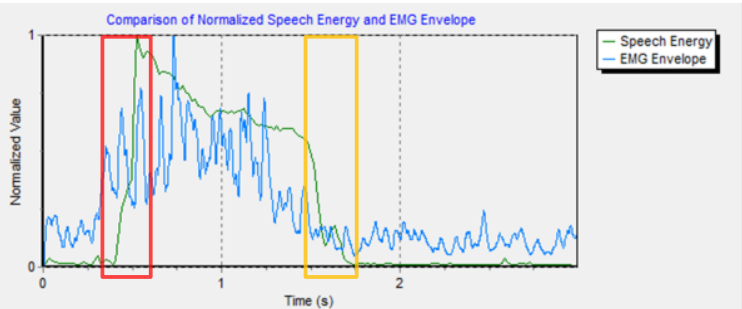

Gambar 12. Perbandingan envelope sinyal EMG dan energi sinyal suara yang telah dinormalisasi.

menghindari/mengurangi delay (transduser mulai bergetar Gambar 11. Sinyal suara terfilter dan hasil autocorrelation-nya. (a) menunjukka lebih lambat dari waktu onset sebernarnya atau berhenti lebih sinyal suara hasil LPF. (b) menunjukkan hasil algoritma autocorrelation dan (c pitch yang terdeteksi.

secara keseluruhan dengan orde 200. Hasil autocorrelation dapat dilihat pada Gambar 11b.

Dari hasil autocorrelation, dapat diperoleh nilai frekuensi fundamental suara terekam dengan menganalisis magnitudo dari time lag terukur. Karena frekuensi fundamental suara manusia dibatasi hingga $350 \mathrm{~Hz}$ maka Rxx di lag di bawah 27 diabaikan. Berdasarkan hasil autocorrelation pada Gambar 11, frekuensi fundamental yang terdeteksi adalah $167 \mathrm{~Hz}$.

E. Analisis Sinyal EMG pada Otot Sternocleidomastoid Terhadap Sinyal Suara

1) Analisis Envelope Sinyal EMG dan Energi Sinyal Suara untuk Mendeteksi Terjadinya Wicara

Envelope sinyal EMG dan energi sinyal suara terekam dibandingkan untuk dianalisis. Grafik hasil envelope sinyal EMG dan energi sinyal suara yang keduanya telah dinormalisasi dapat dilihat pada Gambar 12. Berdasarkan grafik tersebut, dapat dilihat bahwa amplitudo envelope EMG meningkat ketika subjek akan mulai berbicara yang diindikasikan dengan energi sinyal suara yang lebih besar (lihat kotak merah pada Gambar 12). Envelope EMG juga menunjukkan penurunan amplitudo ketika akan berhenti bicara (lihat kotak kuning pada Gambar 12). Berdasarkan analisis tersebut maka dapat dilakukan thresholding dengan mengambil nilai maksimum amplitudo envelope EMG pada segmen energi ketika wicara terdeteksi dan ketika energi wicara tidak terdeteksi lagi.

Nilai amplitudo envelope sinyal EMG maksimum dari segmen ketika subjek mulai berbicara diperoleh dari beberapa sampel/data rekam. Hasil nilai envelope maksimum yang terdeteksi pada subjek dapat dilihat pada Tabel 1. Hasil ratarata dari nilai-nilai tersebut kemudian dijadikan sebagai dasar nilai threshold estimasi aktivasi sinyal eksitator (onset). Nilai amplitudo envelope sinyal EMG maksimum dari segmen ketika subjek akan berhenti berbicara diperoleh dari sampel/data rekam yang sama. Hasil nilai envelope maksimum yang terdeteksi pada subjek dapat dilihat pada Tabel 1. Hasil ratarata dari nilai-nilai tersebut kemudian dijadikan sebagai dasar nilai threshold estimasi penghentian sinyal eksitator (offset).

Penentuan amplitudo envelope sinyal EMG minimum sebagai threshold, baik onset maupun offset, dilakukan secara manual dengan merata-ratakan nilai yang didapat pada semua subjek dan menurunkannya 10\% dengan maksud untuk (cepat dari waktu offset sebernarnya). Pada penentuan threshold, threshold untuk offset harus lebih rendah dari onset untuk menghindari kesalahan deteksi [3].

Berdasarkan hasil thresholding untuk onset dan offset terhadap data EMG yang telah direkam (data offline). Sinyal eksitator aktif lebih cepat dengan rata-rata $0.2 \mathrm{~ms}$ dari sinyal wicara yang terdeteksi. Sementara itu, hal yang sama dilakukan untuk menguji offset threshold. Menggunakan offset threshold yang telah dihitung sebelumnya, sinyal aktuator berhenti dengan rata-rata waktu berhenti $0.12 \mathrm{~ms}$ lebih cepat dari sinyal wicara ketika sudah tidak terdeteksi.

2) Analisis Envelope Sinyal EMG terhadap Pitch Suara

\section{Terdeteksi}

Pengumpulan data sinyal EMG dan sinyal suara yang dilakukan secara bersamaan untuk setiap pengambilan data. Korelasi amplitudo sinyal EMG terhadap pitch kemudian diamati. Berdasarkan data pada Tabel 2, ketika nada yang dihasilkan lebih tinggi, maka amplitudo sinyal EMG trend-nya cenderung meningkat. Akan tetapi hal tersebut tidaklah mutlak. Trend tersebut juga tidak bisa ditunjukkan langsung oleh data yang diperoleh karena jumlah sampel yang terlalu sedikit.

\section{KESIMPULAN}

Perekaman sinyal EMG otot leher dapat dilakukan dengan menggunakan instrumentasi yang terdiri dari penguat instrumentasi dengan rangkaian common-mode rejection, filter analog high pass, low pass, notch filter, dan rangkaian adder.

Berdasarkan hasil analisis pada penelitian ini, sinyal EMG otot leher, dengan konfigurasi peletakan elektroda di otot sternocleidomastoid, pada saat berbicara sangatlah kecil dan dapat diukur dengan baik menggunakan instrumentasi EMG yang dirancang dengan total penguatan lebih dari 2000x.

Otot sternocleidomastoid sendiri merupakan otot leher nonlaryngeal. Berdasarkan perekaman yang dilakukan, proses pembentukan suara ketika berbicara memiliki keterkaitan dengan besar amplitudo sinyal EMG yang dihasilkan.

Metode kalkulasi envelope sinyal EMG low-pass filter dan thresholding dengan dua nilai threshold, onset dan offset, dilakukan untuk mendeteksi wicara. Onset threshold dapat dengan baik mendeteksi wicara sekitar $0.2 \mathrm{~ms}$ sebelum wicara terjadi. Akan tetapi, offset threshold yang ditentukan pada penelitian ini belum mampu mendeteksi berhentinya wicara dengan baik, di mana wicara terdeteksi berhenti lebih cepat sekitar $0.12 \mathrm{~ms}$ dari seharusnya. Hal ini mungkin dapat 
diperbaiki dengan menerapkan threshold adaptif.

Selain untuk mendeteksi wicara, envelope sinyal EMG memiliki korelasi dengan pitch suara yang dihasilkan, yakni pitch suara yang lebih tinggi menghasilkan amplitudo maksimum envelope sinyal EMG yang lebih rendah dan menghasilkan amplitudo maksimum yang lebih tinggi ketika pitch suara lebih rendah.

Adanya pengaruh pembentukan suara dengan aktivitas listrik otot leher nonlaryngeal, memungkinkan sinyal EMG pada leher ini untuk diterapkan selanjutnya sebagai kontrol electrolarynx.

\section{DAFTAR PUSTAKA}

[1] Itzhak Brook, The Laryngectomy Guide. 2013.

[2] T. A. Sardjono, R. Hidayati, N. Purnami, A. Noortjahja, G. J. Verkerke, and M. H. Purnomo, "A preliminary result of voice spectrum analysis from laryngectomised patients with and without electro larynx: A case study in Indonesian laryngectomised patients," Int. Conf. Instrumentation, Commun. Inf. Technol. Biomed. Eng. 2009, ICICI-BME 2009, 2009.

[3] E. A. Goldstein, J. T. Heaton, J. B. Kobler, G. B. Stanley, and R. E. Hillman, "Design and Implementation of a Hands-Free Electrolarynx Device Controlled by Neck Strap Muscle Electromyographic Activity," IEEE Trans. Biomed. Eng., vol. 51, no. 2, pp. 325-332, 2004.

[4] H. L. Kubert et al., "Electromyographic Control of a Hands-Free Electrolarynx Using Neck Strap Muscles," J. Commun. Disord., vol. 42, no. 3, pp. 211-225, 2009.

[5] J. T. Heaton, M. Robertson, and C. Griffin, "Development of a wireless electromyographically controlled electrolarynx voice prosthesis," Proc. Annu. Int. Conf. IEEE Eng. Med. Biol. Soc. EMBS, pp. 5352-5355, 2011.

[6] C. E. Stepp, J. T. Heaton, R. G. Rolland, and R. E. Hillman, "Neck and face surface electromyography for prosthetic voice control after total laryngectomy," IEEE Trans. Neural Syst. Rehabil. Eng., vol. 17, no. 2, pp. 146-155, 2009.

[7] F. Ahmadi, M. Araujo Ribeiro, and M. Halaki, "Surface electromyography of neck strap muscles for estimating the intended pitch of a bionic voice source," IEEE 2014 Biomed. Circuits Syst. Conf. BioCAS 2014 - Proc., pp. 37-40, 2014.

[8] K. Oe, S. Kokushi, and R. Nakamura, "Proposal of new control parameter for neck myoelectric control-type electrolarynx," MHS 2017 - 28th 2017 Int. Symp. Micro-NanoMechatronics Hum. Sci., vol. 2018-January, pp. 12, 2018.

[9] F. Arifin, T. A. Sardjono, and M. H. Purnomo, "the Relationship Between Electromyography Signal of Neck Muscle and Human Voice Signal for Controlling Loudness of Electrolarynx," Biomed. Eng. Appl. Basis Commun., vol. 26, no. 05, p. 1450054, 2014.

[10] L. F. Brosnahan and B. Malmberg, "The Production of Sound in the Vocal Tract," in Introduction to Phonetics, Cambridge: Cambridge University Press, 1976.

[11] B. H. Story, "Mechanisms of Voice Production," in The Handbook of Speech Production, West Sussex: John Wiley and Sons, 2015.

[12] J. Webster, "Elektromyography," Encycl. Med. devices Instrum., pp. 98$109,2006$.

[13] C. J. De Luca, "Delsys Surface Electromyography: Detection and Recording," Delsys Inc., vol. 10, no. 2, pp. 1-10, 2002.

[14] D. Erickson, T. Baer, and K. S. Harris, "The role of the strap muscles in pitch lowering," Haskins Laboratories Status Report on Speech Research, vol. SR-70. pp. 275-284, 1983.

[15] S. Yu, T. Lee, and M. L. Ng, "Surface electromyographic activity of nonlaryngeal neck muscles in Cantonese tone production," Proc. 9th Int. Symp. Chinese Spok. Lang. Process. ISCSLP 2014, pp. 304-307, 2014.

[16] C. Kitchin and L. Counts, A Designer's Guide To Instrumentation Amplifiers, vol. 3. 2006.

[17] S. A. Pactitis, Active Filters: Theory and Design. CRC Press, 2007.

[18] M. N. Horenstein, "Active Filters and Oscillators," in Microelectronic Circuits and Devices, Prentice Hall, 1996.

[19] L. R. Altimari, J. L. Dantas, M. Bigliassi, T. F. D. Kanthack, A. Carlos de Moraes, and T. Abrão, "Influence of Different Strategies of Treatment Muscle Contraction and Relaxation Phases on EMG Signal Processing and Analysis During Cyclic Exercise," in Computational Intelligence in Electromyography Analysis - A Perspective on Current Applications and Future Challenges, InTech, 2012.

[20] A. K. Fuchs, C. Amon, and M. Hagmüller, "Speech/Non-Speech Detection for Electro-Larynx Speech Using EMG," in Proceedings of the International Conferenceon Bio-inspired Systems and Signal Processing (BIOSIGNALS-2015), 2015, pp. 138-144. 